\title{
Eosinophil otitis media - egy kevéssé ismert kórkép kezelési nehézségei
}

\author{
Révész Péter dr. ${ }^{1}$ - Gerlinger Imre dr. ${ }^{1}$ - Kálmán Endre dr. ${ }^{2}$ \\ Alexandros Koukkoullis dr. ${ }^{1}$. Burián András dr. ${ }^{1}$. Tóth István dr. ${ }^{1}$ \\ ${ }^{1}$ Pécsi Tudományegyetem, Általános Orvostudományi Kar, Klinikai Központ, Fül-, Orr-, Gégészeti és Fej-, \\ Nyaksebészeti Klinika, Pécs \\ ${ }^{2}$ Pécsi Tudományegyetem, Általános Orvostudományi Kar, Klinikai Központ, Pathologiai Intézet, Pécs
}

\begin{abstract}
Az eosinophil otitis media az utóbbi évtizedben került a kutatók és a klinikum látóterébe; jellemzője a középfülben termelődő, eosinophil granulocytákkal telített mucosus, nehezen eltávolítható váladék és az asthma bronchiale, valamint a krónikus rhinosinusitis társulása. A betegség egyelőre kevéssé ismert a klinikumban, emiatt nincsenek információk a pontos előfordulási gyakoriságáról sem. A kórkép nem gyógyítható, de kezelésére beváltak az intratympanalisan használható szteroidkészítmények, melyek azonban csak enyhébb fokú betegség esetén vezetnek eredményre. A súlyosabb gradusú eosinophil otitis media dobüregi granulációs szövet képződésével és idegi halláscsökkenéssel is járhat, ami sebészi eltávolítást és per os szteroidkezelést is igényel. Fontos felhívni a figyelmet a kórkép létezésére, mert a megfelelő diagnózis felállítása után az időben elkezdett kezeléssel elkerülhető lehet az életminőséget rontó fülváladékozás, felülfertőződés és az idegi halláscsökkenés. A jelen közleményben a szerzők a nemzetközi szakirodalom áttekintésén túl saját esetbemutatásokon keresztül demonstrálják a betegség enyhe és súlyos fokú változatának kezelési lépéseit.
\end{abstract}

Orv Hetil. 2020; 161(41): 1769-1775.

Kulcsszavak: eosinophil otitis media, intratympanalis szteroid, subtotalis petrosectomia

\section{Eosinophilic otitis media - challenges of a lesser-known disease}

Eosinophilic otitis media (EOM) is a recently diagnosed disease that gained popularity among researchers and clinicians in the last decade. The disease is characterized by hardly removable discharge and dominantly eosinophilic thick mucus that fills the middle ear and is frequently associated with bronchial asthma and chronic rhinosinusitis. Currently, the disease is not well known resulting in the lack of precise incidence data. Up to date, the disorder is incurable but intratympanic steroids may lead to symptom relief in mild cases. Severe cases are characterized by granulation tissue formation and sensorineural hearing loss requiring surgical intervention and administration of oral steroids. It is of paramount importance to draw attention to the existence of this condition, since promptly administered effective therapy can help to avoid complications such as a discharging ear, superinfection and sensorineural hearing loss. In addition to reviewing the current literature, we publish our case presentations of both mild and severe cases and their management.

Keywords: eosinophilic otitis media, intratympanic steroid, subtotal petrosectomy

Révész P, Gerlinger I, Kálmán E, Koukkoullis A, Burián A, Tóth I. [Eosinophilic otitis media - challenges of a lesserknown disease]. Orv Hetil. 2020; 161(41): 1769-1775.

(Beérkezett: 2020. április 15.; elfogadva: 2020. május 20.)

\section{Rövidítések}

BAHA = (bone-anchored hearing aid $)$ csontba ágyazott hallásjavító készülék; CRS = (chronic rhinosinusitis) rhinosinusitis chronica; $\mathrm{CRSwNP}=$ (chronic rhinosinusitis with nasal polyps) rhinosinusitis chronica polyposa; EOM = eosinophil otitis media; FESS = (functional endoscopic sinus surgery) funkcionális endoszkópos orrmelléküreg-sebészet; $\operatorname{IgE}$ = immunglobulinE; IL-5 = interleukin-5; IT = intratympanalis; MPO-ANCA = mieloperoxidáz elleni antineutrofil citoplazmatikus antitest; $\mathrm{OR}=($ odds ratio $)$ esélyhányados; PR3-ANCA = proteináz-3 elleni antineutrofil citoplazmatikus antitest; PTE = Pécsi Tudományegyetem 
$\mathrm{Az}$ eosinophil otitis media (EOM) kórképet először Tomioka és mtsai írták le 1997-ben az eosinophil sejteket tartalmazó, mucosus váladékkal kísért otitis media elnevezésére [1]. A betegség diagnosztikai kritériumait Iino és mtsai ismertették 2011-ben, amelyek szerint a major diagnosztikai feltétel az eosinophil sejtek jelenléte a középfül váladékában [2]. A minor kritériumok közé tartozik a sürü, mucosus dobüregi váladék, a konvencionális kezelésre nem reagáló fülstatus, az elváltozáshoz társuló asthma bronchiale, illetve az orrpolyposis [2]. Az előbbi szerzők szerint a major kritérium mellé társuló bármely, előbb említett 2 minor kritérium esetén a diagnózis biztosra vehető [2]. EOM esetén a dobüregi váladék eosinophil gyulladásos marker koncentrációja emelkedett (eosinophil kationos protein jelenléte), emellett magas az interleukin-5 (IL-5)- és az eotaxinszint is, melyek együttesen a középfülben zajló aktív eosinophil sejtes gyulladást jelzik [3-5]. A betegség elsősorban az 50-60 éves populációt érinti, a betegek többsége nő [2]. Az EOM-hoz gyakran társul asthma (esélyhányados [OR] $584,5]$ és rhinosinusitis chronica polyposa (CRSwNP, OR 42,17), az EOM tüneteinek megjelenése azonban általában több mint 10 évvel későbbre tehető az asthma és a CRSwNP kialakulásához képest $[2,6]$. Az eosinophil gyulladás a középfül nyálkahártyáját eltérő mértékben érinti; 1. fokú betegség esetén a nyálkahártya makroszkóposan ép; 2. fokú EOM a középfül nyálkahártyájának körülírt duzzanatát okozza; 3 . fokú betegség esetén duzzadt nyálkahártya vagy granulációs szövet jelenik meg a dobüregben, amely a külső hallójáratba terjed. A legsúlyosabb fokozathoz gyakran társul cukorbetegség és kontrollálatlan asthma is [7]. Iino és mtsai 138, EOM miatt kezelt beteg követése során az esetek több mint felében a csontvezetéses küszöb romlását mérték, a betegek 6\%-a pedig idővel teljesen elvesztette a hallását [2]. A kezelés a betegség gradusától függ: 1. fokú EOM esetén intratympanalis (IT) szteroidinjekció javasolt (például triamcinolon-acetonid $20 \mathrm{mg} / 0,5 \mathrm{ml}$ ) havonta 1 vagy több alkalommal; 2 . fokú betegség az IT szteroid mellett szisztémás szteroiddal kezelendő, ha a belső fül érintettsége is fennáll; 3 . gradus esetén a granulációs szövet sebészi eltávolítása és szteroiddal átitatott Gelfoam IT elhelyezése javasolt [8]. A dobüregi váladék mikrobiológiai vizsgálata elengedhetetlen, pozitív leoltás esetén célzott szisztémás antibiotikum adása szükséges [8]. Amennyiben a 3. fokú, granulációs szövet képződésével kísért EOM nem javul sem az IT, sem a szisztémás szteroid adására, akkor indokolt a sebészi ellátás. Fülfolyás esetén, különösen, ha a páciens hallásjavító készüléket visel, a granulációs szövet helyi érzéstelenítésben történő eltávolítása és szteroiddal átitatott Gelfoam dobüregi elhelyezése javasolt dobhártya-perforáción keresztül, mert a helyi szteroidkészítmény segítségével meghosszabbodhat a fülfolyásmentes periódus [9]. Amennyiben a granulációs szövet recidivál IT és szisztémás szteroid adása ellenére is, akkor radikális mútéti megoldás javasolható, mely mellett a halláscsökkenés mértékétől függő implan- tációs megoldások is szóba jönnek. Ha az érintett oldalon súlyos fokú halláscsökkenést vagy siketséget regisztrálunk, akkor subtotalis petrosectomiával egy ülésben a hallás rehabilitációja is megoldható cochlearis implantátum segítségével [10]. Amennyiben vezetéses vagy 45 dB-nél nem rosszabb idegi komponenssel társult, kevert típusú halláscsökkenés áll fenn, akkor csontvezetéses implantátumnak a subtotalis petrosectomiával szimultán végzett behelyezése jelentheti a legeredményesebb mútéti megoldást a hallás javításával egyetemben [11]. Az egyéb, eosinophiliával kísért kórképektől (ChurgStrauss-szindróma, hypereosinophil szindróma) való elkülönítést a vérképvizsgálat, valamint a szérum-PR3ANCA- és -MPO-ANCA meghatározása segíti. Esetismertetéseink során egy 1. fokú és egy 3. fokú EOM miatt kezelt páciens kórtörténetét mutatjuk be.

\section{Első eset}

Egy 69 éves nőbeteg 2019 őszén jelentkezett a PTE Fül-, Orr-, Gégészeti és Fej-, Nyaksebészeti Klinikáján kétoldali füldugulás miatt. A páciens kórtörténetéből kiemelendő az évtizedek óta kezelt asthma, a CRSwNP és az alvási apnoe szindróma. Mometazontartalmú orrspray mellett tiotropiumot, valamint budezonid és formoterol hatóanyag-kombinációjú inhalátort használt, és montelukasztot szedett előírás szerint. Konzervatív kezelésre nem reagáló CRSwNP miatt 1995-ben külső feltárásból végzett arcüregmútéten esett át (op. sec. Luc-Caldwell), majd recidiv orrpolyposis miatt 2007-ben és 2012-ben is funkcionális endoszkópos orrmelléküreg-sebészeti beavatkozás (FESS) történt Klinikánkon. Az első FESSmútét alkalmával egy ülésben kétoldali ventilációstubusbehelyezést is végeztünk, kétoldali krónikus savós

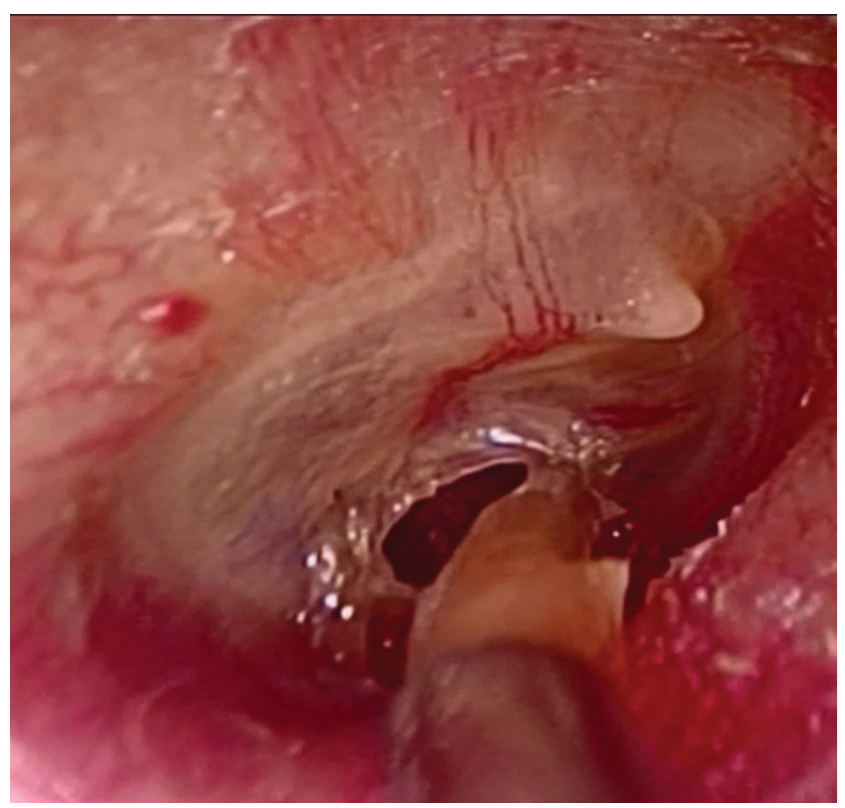

l. ábra $\quad$ A dobüreget kitöltő sűrű, nehezen leszívható mucosus váladék jellemző az eosinophil otitis mediára 


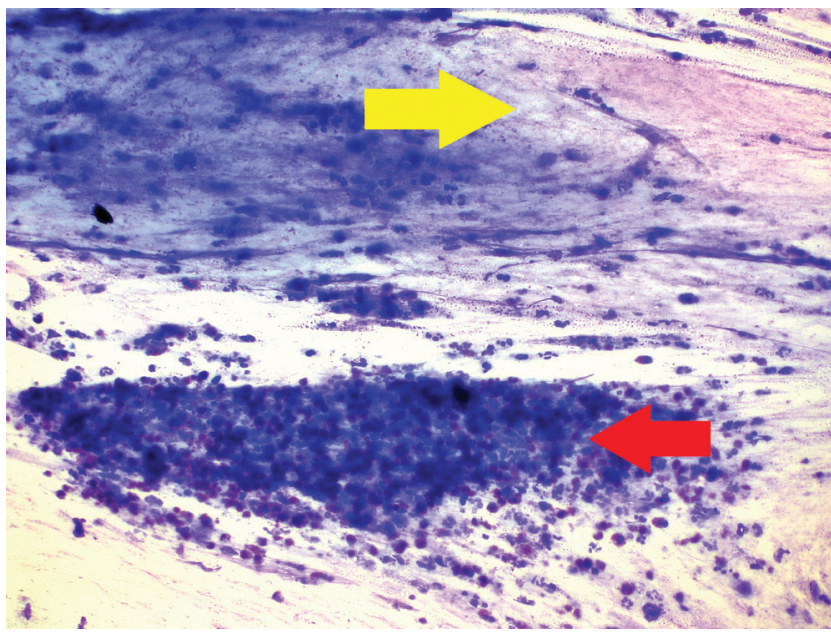

2. ábra

A középfül váladékáról készült kenet. A felső félben sưrúu, szálcsás, szemcsés nyákfilm látszik (sárga nyíl), az alsó félben sejthalmaz nagyszámú eosinophil sejttel (piros nyíl, 20×-os Giemsafestés)

otitisnek imponáló klinikai kép miatt. Az elmúlt években több alkalommal történt a tubusok cseréje, mert a középfülben jelen lévő sûrű, mucosus nyák eltömítette a ventilációs tubusok lumenét (1. ábra). A legutóbbi, 2019-ben végzett tubuscsere alkalmával a dobüregi váladékot citológiai vizsgálatra küldtük, és Giemsa-festett kenetben vizsgálva a mintát, vastag nyákrétegben tömegesen jelen lévő eosinophil sejteket igazoltunk. A minta asthma bronchiale mellett észlelt, sưrű nyákra emlékeztetett (leletszám: $39186-2019 ; 2$ ábra). A klinikai és a patológiai lelet alapján felállítottuk az eosinophil otitis media diagnózisát; a betegséget a dobüregi status miatt az 1. gradusba soroltuk, és a ventilációs tubuson keresztül IT szteroidfeltöltést végeztünk mindkét oldalon (dexametazon $4 \mathrm{mg} / \mathrm{ml} ; 3$ ábra). A dobüregi váladékozás

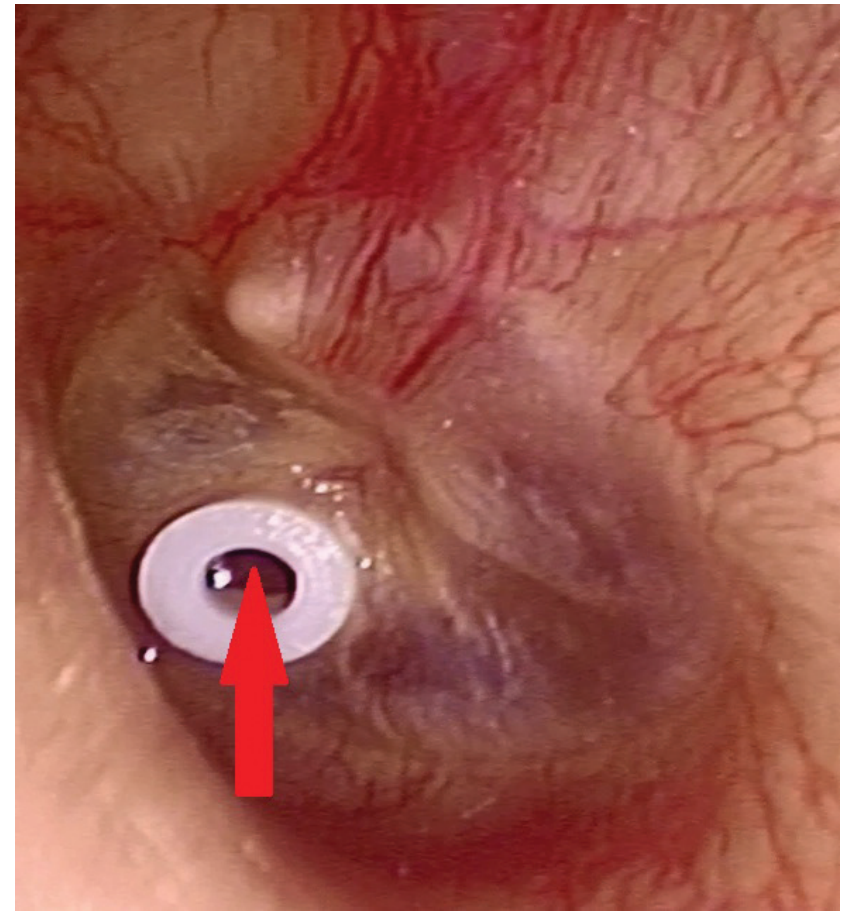

3. ábra

A bal oldali dobüreget kitöltő szteroidoldat látható a ventilációs tubus lumenén keresztül (nyíl)

már az első kezelést követően megszünt mindkét oldalon, majd a bal oldalon 2 hét elteltével újra megjelent. A jobb fülben 3 hét elteltével sem termelődött újra a mucosus váladék. A beszédfrekvenciák átlagán mért csontvezetéses küszöb a jobb oldalon 11,25 dB-t, a bal oldalon $10 \mathrm{~dB}$-t javult 4 hónappal a kezelés megkezdését követően; a csont-lég rés a bal oldalon $5 \mathrm{~dB}$-t javult, a jobb oldalon pedig változatlan maradt (4. ábra). A páciens az eltelt 4 hónap alatt 4 alkalommal esett át IT szte-
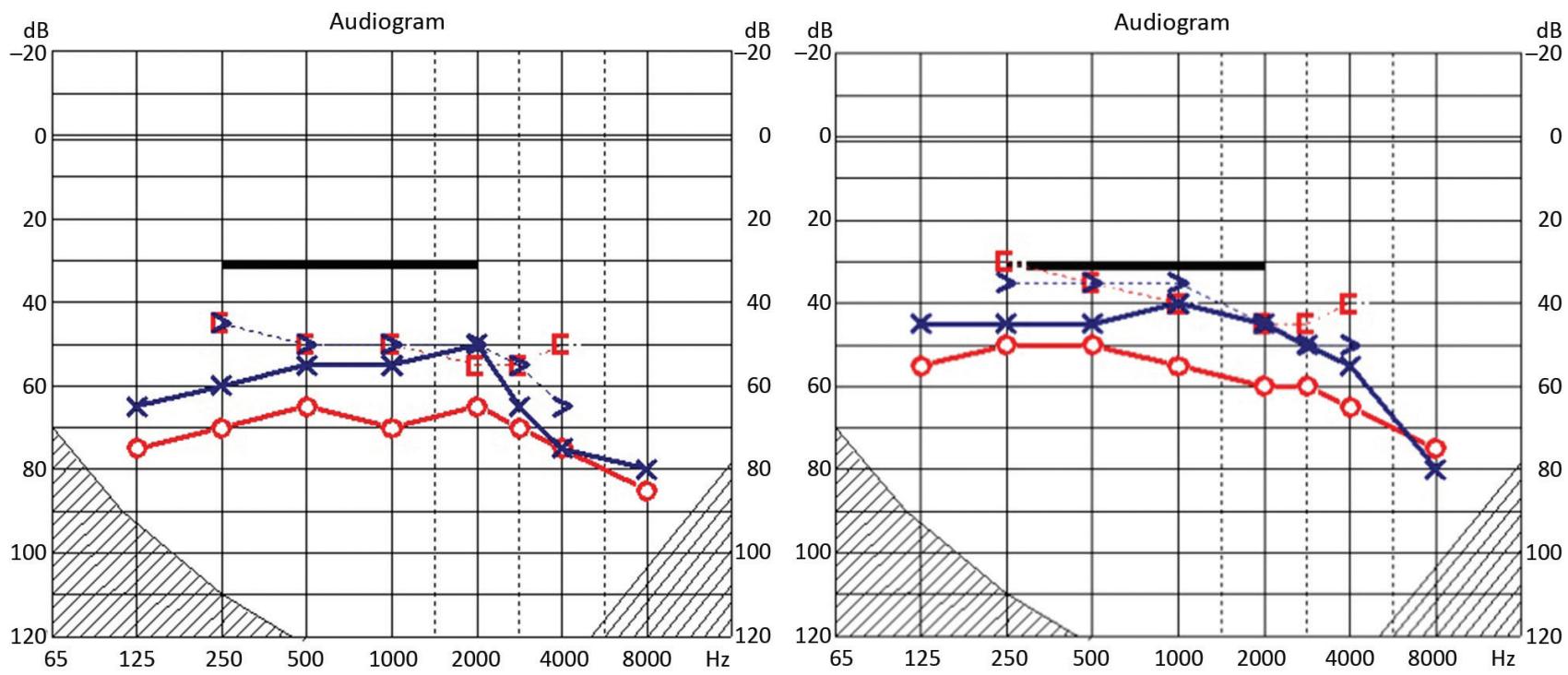

4. ábra $\quad$ A bal oldali audiogramon az IT szteroidkezelés előtti hallásküszöb látható, a jobb oldali audiogramon 4 hónappal az első kezelést követően mért hallásküszöb (kék: bal fül, piros: jobb fül)

$\mathrm{IT}=$ intratympanalis 


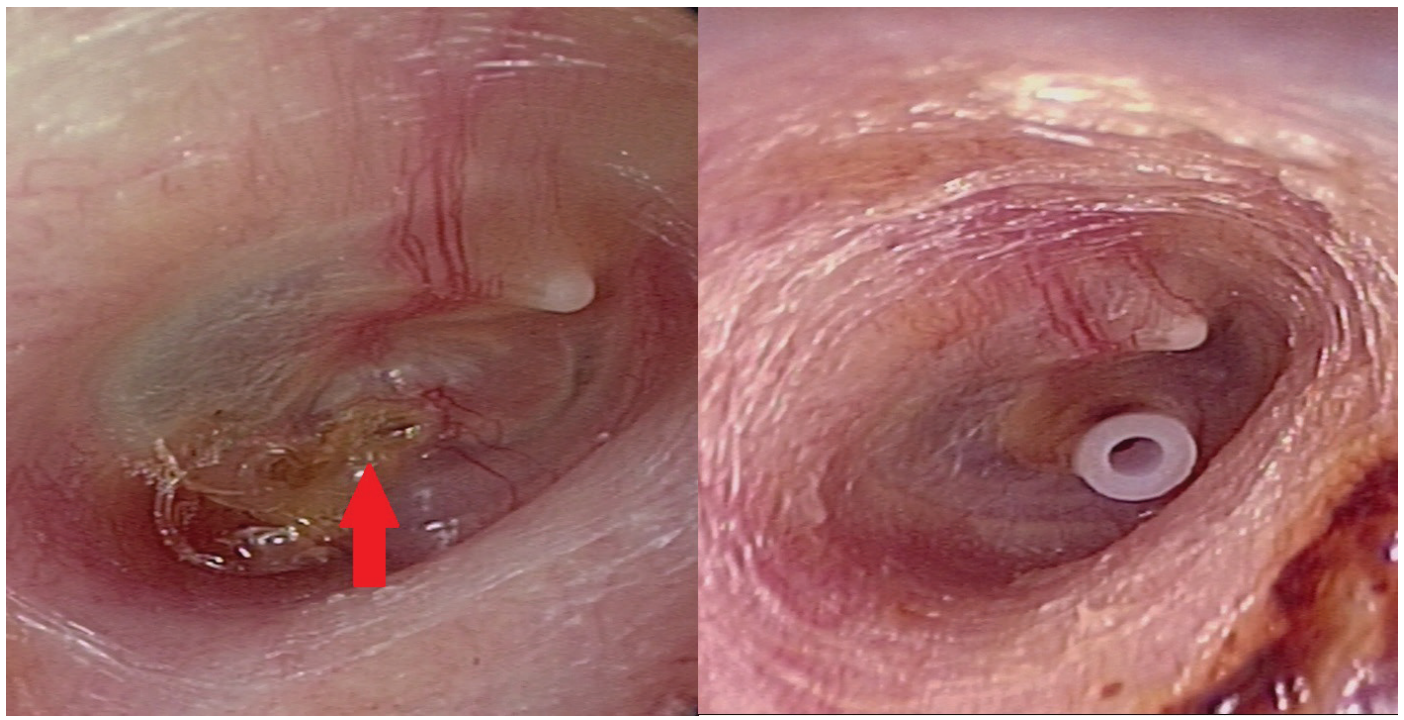

5. ábra

A bal oldali képen beszáradt váladék látható a myringotomiás nyílásban (nyíl), a jobb oldali képen jól vezető ventilációs tubus látható gyulladásmentes környezetben 4 hónappal a kezelés megkezdését követóen

roidfeltöltésen, kontrollját 2 hetente végezzük (5. ábra). A páciens otthoni gyógyszerelésén nem változtattunk, továbbra is az asthma miatt indikált terápiát alkalmazza.

\section{Második eset}

Az 58 éves nőbeteget 30 éve fennálló kétoldali, savós, illetve gennyes otitis miatt kezelték más intézetben, több alkalommal végeztek kétoldali ventilációstubus-behelye- zést és l alkalommal jobb oldali mastoidectomiát. Anamnézisében hypertonia és gyógyszeresen kezelt, 2-es típusú diabetes mellitus szerepelt. A páciens 2013-ban kereste fel Klinikánkat visszatérő halláscsökkenése miatt. A kórelőzményben szereplő eredménytelen ventilációstubus-inszerciókra tekintettel kétoldali ballonkatéteres fülkürttágítást végeztünk 2013-ban, majd 2014-ben is, a beavatkozások azonban a jobb oldali dobüregi mucosus váladék megjelenését érdemben nem befolyásolták. A bal

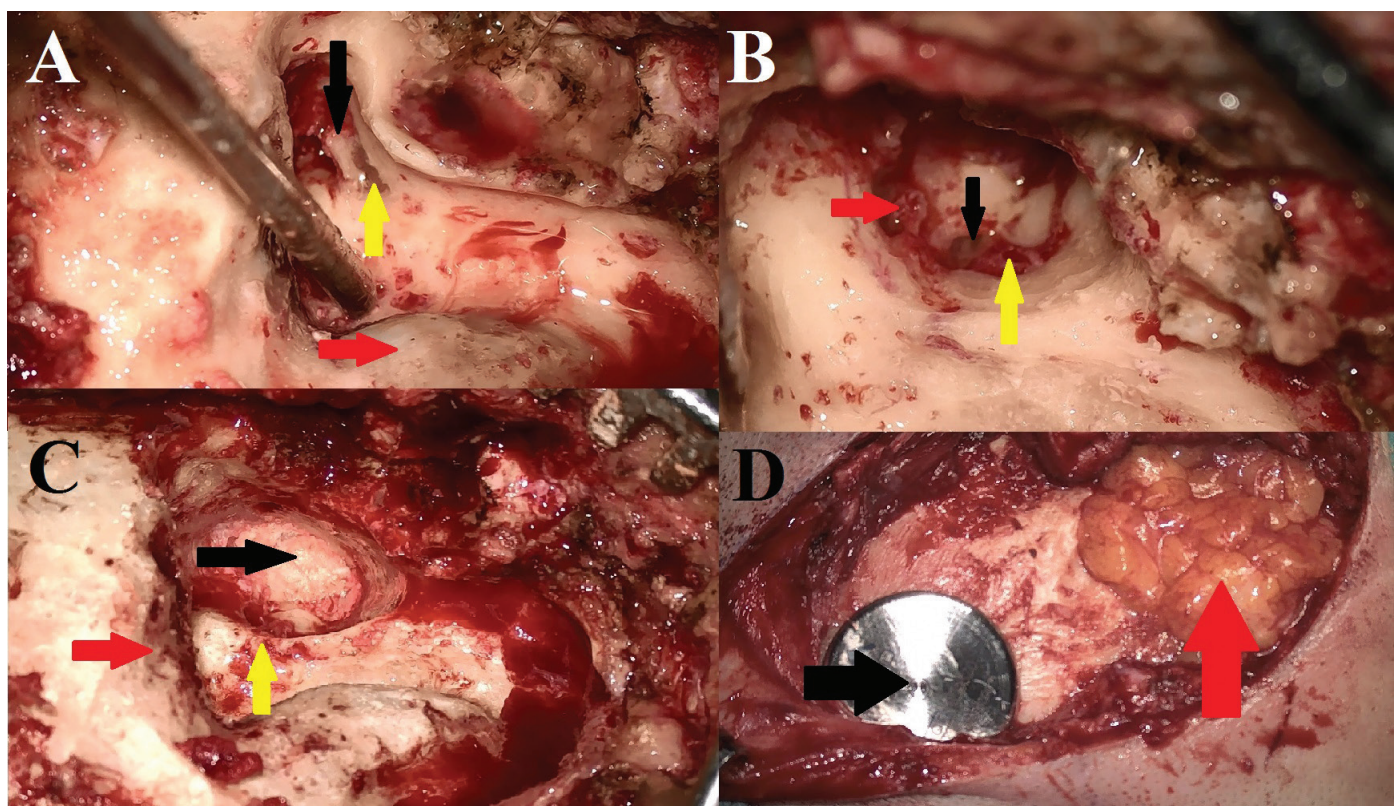

6. ábra

Jobb oldali subtotalis petrosectomia mútéti lépései BAHA-behelyezéssel. A: Komplettált mastoidectomia, látható a dobüregben lévő mucosus váladék (sárga nvíl: mucosus váladék; fekete nyíl: incus rövid nyújtvány; piros nyíl: sinus sigmoideus). B: Kidolgozott dobüregi csontmunka a sinus tympanicusban látható residualis granulációs szövettel (sárga nyíl: granulációs szövet; fekete nyíl: kerek ablak; piros nyíl: stapes). C: Komplettált subtotalis petrosectomia mútéti területe, nyálkahártya és granulációs szövet már nem látható (fekete nyíl: csontviasszal obliterált fülkürtszájadék; sárga nyíl: nervus facialis; piros nyíl: középső skála durát borító csontlemez). D: Hasfali zsírral obliterált műtéti terület (piros nyíl) és az implantált BAHA Attract (fekete nyíl)

BAHA = csontba ágyazott hallásjavító készülék 
oldali dobüreg légtartóvá vált. A jobb oldali dobhártyán ezt követően lézeres perforációt képeztünk, a perforáció azonban spontán záródott. A jobb oldali fülstatus nem javult sem IT, sem szisztémás szteroid adására. Audiogramon ép csontvezetéses hallásküszöb mellett közepesnagy fokú vezetéses halláscsökkenést mértünk. Tekintettel arra, hogy a jobb oldali fülstatusa a szisztémás szteroidra sem reagált, illetve a páciens a több évtizede visszatérő fülfolyás tartós megszüntetését kérte, műtéti megoldásként subtotalis petrosectomiát javasoltunk, melynek során a mucosus váladékot termelő középfülnyálkahártya eltávolításra került. A páciens panaszait a subtotalis petrosectomiával egy ülésben végzett BAHAimplantációval oldottuk meg 2019 áprilisában (op.: Gerlinger prof.; 6. ábra). A mútét előtt a beszédfrekvenciák átlagán mért 43,75 dB-es átlagos légvezetéses küszöb posztoperatív 41,25 dB-re változott a bekapcsolt csontvezetéses készülékkel (7. ábra).

\section{Megbeszélés}

Az EOM problémaköre az utóbbi években került a kutatás és a klinikum előterébe. A betegség megállapításához fontos a részletes anamnézis felvétele, ami önmagában nagy segítséget nyújt a kórkép felismeréséhez. Jellemző a többéves kórelőzmény, a ventilációstubus-behelyezést követően sem csökkenő középfül-váladékozás és az aszszociáció krónikus légúti betegségekkel (asthma és CRS) [12]. A kórképet sem antibiotikum, sem konzervatív fülsebészeti beavatkozás nem gyógyítja, egyes szerzók a tympanoplasticát és/vagy a mastoidectomiát is kerülendőnek tartják $[7,9]$. Jellegzetes anamnézis esetén tekintettel kell lennünk a dobüregi váladék vizsgálatára, mert a betegség diagnózisának alapja az exsudatum citológiai leletezése [2]. A minta helyi érzéstelenítést követően paracentesis során kinyerhető, majd natívan vagy formalinban fixálva citológiai vizsgálatra küldendő. A betegség major diagnosztikai kritériuma az eosinophil sejtek domináns jelenléte a mintában. Több szerző szerint az EOM gyakorisága jóval magasabb, mint azt korábban feltételezték, különösen asthmás és aszpirinintoleráns betegek vonatkozásában $[9,13]$. Tekintettel arra, hogy az EOM még nem képezi a rutin szakorvosi gondolkodás részét, a diagnosztizált esetek száma alulmúlhatja a betegség valós előfordulását. A betegség oka nem teljesen tisztázott, az emelkedett dobüregi IgE-szintet az I. típusú allergiás reakció mellett a középfülbe került gombák (Aspergillus, Alternaria) és baktériumok is okozhatják (Staphylococcus aureus) [6, 14]. A kórkép széles körben elfogadott ajánlás szerint szteroiddal kezelendő [9, 10, 15]. Az IT alkalmazott készítmények közül elsősorban a triamcinolon-acetonid $(40 \mathrm{mg} / \mathrm{ml})$ terjedt el a gyakorlatban $[9,10]$. A hatóanyag-molekula oldhatatlan, féléletideje parenteralis adagolás esetén 18-36 óra, aminek alapján a közepes hatástartamú szteroidok közé tartozik. Hatáserőssége ötször nagyobb a hidrokortizonhoz képest [16]. Az első esetismertetésben bemutatott páciens kezelésére a dexametazont választottuk (Dexa-ratiopharm $4 \mathrm{mg} / \mathrm{ml}$ ), mert a hidrokortizonhoz képest mért relatív hatáserőssége 25 -szörös, és hosszú hatástartama mellett IT alkalmazása biztonságos [16, 17]. Az l. fokú EOM IT szteroidra adott jó terápiás válaszát több szerző is alátámasztja [7, 9]. Esu és mtsai 96, 1. fokú EOM miatt kezelt betegből 95-nél tapasztaltak dobüregi váladékcsökkenést a középfülbe juttatott szteroid hatására [7]. Iino és mtsai 81\%-os hatásosságot írtak le több mint 3 héttel az 1 . IT szteroidbeadást követően [9]. A legtöbb esetben elegendőnek tartják a havi l vagy
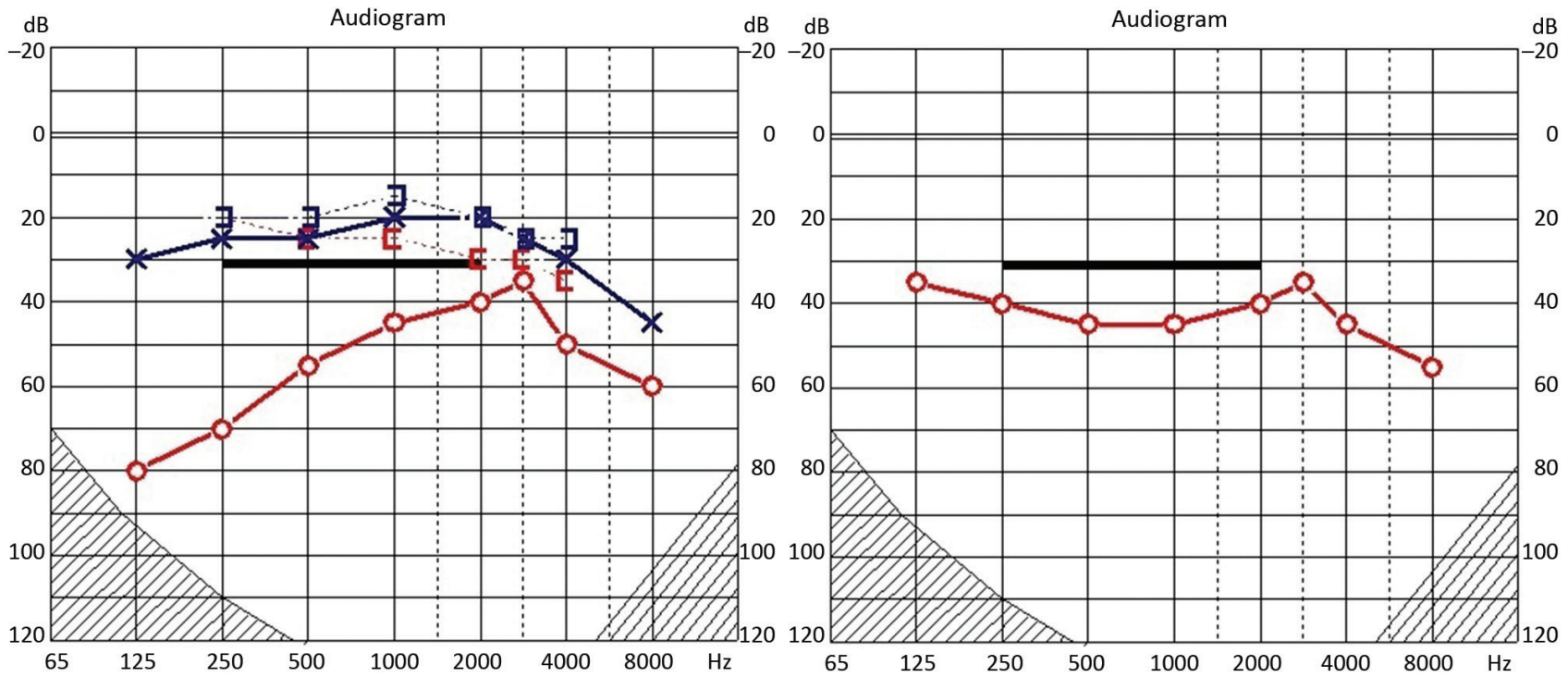

7. ábra $\quad$ A bal oldali audiogramon a mútét előtti hallás látható (kék: bal fül; piros: jobb fül), a jobb oldali audiogramon a posztoperatív hallás látható szabad hangtérben regisztrálva bekapcsolt BAHA Attract implantátum mellett

BAHA = csontba ágyazott hallásjavító készülék 
több alkalommal ambuláns körülmények között végzett IT szteroidfeltöltést, enyhébb esetben az intervenció ritkábban is elvégezhető [10]. Esetünkben ventilációs tubuson keresztül végeztük az IT szteroidfeltöltést, a tubusbehelyezést azonban a legtöbb szerző feleslegesnek vagy ellenjavalltnak tartja, mert a tubus lumenét a mucosus váladék könnyedén obliterálhatja $[9,10,15]$. Más szerzők szerint viszont a ventilációs tubus a lokális szteroid és antibiotikum bejutási útvonalát is jelentheti [7, 9]. Első esetünknél a jobb oldali ventilációs tubus több alkalommal obliterálódott, de szívóval minden esetben sikerült a beszáradt váladékot eltávolítani. A tubusbehelyezés oka a relatíve fájdalommentes gyógyszeradagolás volt, ismétlődő elzáródás esetén azonban a későbbiekben a tubus eltávolítására kényszerülhetünk. A 3. fokú EOM miatt kezelt betegek terápiás válasza ellenben lényegesen rosszabb a dobüregi szteroid hatására. Esu és mtsai 18 beteg közül 1-nél tapasztaltak állapotjavulást, abban az esetben a 3 . fokú EOM 1 . fokúvá mérséklődött [7]. A fennmaradó 17 esetnél a szisztémásan adott szteroid sem tudta megakadályozni a granulációs szövet későbbi megjelenését. A szerzők 14 fül esetében helyi érzéstelenítésben végzett műtét során a granulációs szövetet a perforált dobhártyán keresztül eltávolították, majd a dobüregbe szteroiddal átitatott zselatinszivacsot helyeztek 1 hétig. A beavatkozás hatására 12 esetben 2 . fokúvá mérséklődött a betegség [7]. A hallás változása a kórkép gradusával és a dobüregi IgE koncentrációjával is összefüggést mutat, és jellemzően a $2-4 \mathrm{kHz}$-es frekvenciatartományt érinti $[7,8]$. Esu és mtsai szignifikánsan rosszabb lég- és csontvezetéses értékeket mértek 3. fokú EOM miatt kezelt betegek küszöbaudiometriája során az 1. fokú betegséggel kezeltekhez képest [7]. Iino és mtsai tanulmányában a különböző súlyossági fokozatokhoz társult csontvezetéses küszöbértékek szignifikánsan eltértek egymástól, a 3. fokú betegség okozta a legroszszabb csontvezetéses értékeket [2]. Az idegi hallásromlás hátterében az eosinophil granulocytákból és a baktériumokból származó gyulladásos anyagok állhatnak, melyek a kerek ablakon keresztül érik el a csigát [2]. Az eosinophil granulocytákból kiszabaduló eosinophil kationos protein, az IL-5, valamint bakteriális felülfertőződés esetén a bakteriális toxinok is átjuthatnak a kerek ablakon, és károsíthatják a belső fül struktúráit [3-5, 18, 19]. Esu és mtsai az l. fokú populáció (96 fül) 90,6\%-ánál mértek hallásjavulást vagy stabil hallást IT szteroid hatására; a 2. fokú betegcsoportban (22 beteg) ez az érték 72,7\% volt, a 3 . fokú esetek (18 beteg) döntő többségénél azonban hallásromlás állt be a kezelés mellett $(72,2 \%)$, hallásjavulást pedig nem értek el [7]. $10 \mathrm{~dB}$-t meghaladó, 2-nél több frekvenciát érintő csontvezetéses romlásnál szisztémás szteroiddal egészítették ki az IT kezelést [7]. Iino és mtsai 43 esetben végzett IT triamcinolonkezelés hatásosságát vetették össze EOM miatt nem kezelt kontrollcsoporttal (27 eset), és szignifikáns hallásjavulást mértek a légvezetéses értékek átlagán, miközben a csontvezetésben nem tapasztaltak változást a kezelt csoportban.
A nem kezelt eseteknél a csontvezetéses küszöb átlaga viszont szignifikánsan rosszabb lett a vizsgálat végén. A kezelt populáció vegyesen tartalmazott enyhe és súlyosabb fokú betegeket is [9]. Az első esetismertetésünkben bemutatott beteg hallása a kezelés hatására javult, a beszédfrekvenciák átlagán $(0,5,1,2,3 \mathrm{kHz}$ átlaga $)$ mért légvezetéses küszöb 11,25 dB-lel lett jobb a kezelés előtti értékekhez képest. Az előbbi frekvenciákon mért csontvezetéses küszöb átlaga a jobb oldalon $11,25 \mathrm{~dB}-\mathrm{t}$, a bal oldalon pedig $10 \mathrm{~dB}-\mathrm{t}$ javult a 4 hónapos kezelés hatására. A szerzők hangsúlyozzák a granulációs szövet eltávolításának fontosságát annak érdekében, hogy megfelelő hely álljon rendelkezésre a szteroid IT alkalmazására, más szerzők pedig szteroiddal átitatott zselatinszivacs dobüregi elhelyezését is javasolják a hosszabb hatástartam eléréséért [7, 9]. Konzervatív kezelésre és helyi érzéstelenítésben kivitelezett granulációsszövet-eltávolításra sem reagáló 3. fokú EOM esetén a halláscsökkenés mértékétől függően pedig szóba jöhet hallásjavító implantátumnak subtotalis petrosectomiával egy ülésben végzett behelyezése is (cochlearis implantáció, csontvezetéses implantátum). $45 \mathrm{~dB}$-t meg nem haladó csontvezetéses küszöb esetén BAHA Attract (Cochlear Ltd., Sydney, Ausztrália) vagy BoneBridge (Med-El GmbH, Innsbruck, Ausztria) csontvezetéses implantátum, 55 dB-nél nem rosszabb küszöbnél BAHA 5 Power (Cochlear Ltd., Sydney, Ausztrália), átlagosan 65 dB-t meg nem haladó csontvezetéses küszöbnél pedig BAHA 5 SuperPower (Cochlear Ltd., Sydney, Ausztrália) csontvezetéses implantátum javasolható hallásrehabilitáció céljából $[11,20]$. Siketséggel határos halláscsökkenés vagy siketség esetén az érintett oldali hallás rehabilitációjához a cochlearis implantáció jöhet szóba. Sugimoto és mtsai lokális és szisztémás szteroidra nem reagáló, 3. fokú EOM miatt siketté vált betegeknél végeztek subtotalis petrosectomiát, a hallást cochlearis implantációval rehabilitálták [21]. A subtotalis petrosectomia radikális beavatkozás, a középfül üregrendszerének megszüntetését, a sziklacsontban levő sejtrendszer maradéktalan eltávolítását foglalja magában, a sziklacsontcsúcsi sejtek megkímélésével [22]. A mútét az alapelvéből adódóan nagyfokú vezetéses halláscsökkenést okoz. EOM esetén azonban a mucosus váladékot termelő nyálkahártya eltávolításával az életminőséget rontó otorrhoea és a potenciális felülfertőződés veszélye is megszűnik. A beavatkozás a külső hallójárat lezárásával jár (cul-de-sac), emiatt nincs lehetőség a konvencionális hallásjavító készülék viselésére. Esetünkben a páciens BAHA Attract implantátumot kapott; a subtotalis petrosectomia okozta további halláscsökkenést sikerült a mütét előtti hallásnak megfelelően rehabilitálni, mert az operált oldalon kisközepes fokú halláscsökkenést mértünk. A páciens ellenoldali hallása közel ép volt. Fülfolyása megszűnt, az operált fül „uszodabiztossá” vált. Az EOM kezelését célzó újabb gyógyszerekről több tanulmány is beszámolt, azonban mind az anti-Ig-E-hatású omalizumab, mind az 
IT adott interferon- $\alpha-2 a$ és - $2 b$ csak az enyhébb fokú EOM kezelésében tünt ígéretesnek, a 3. fokú betegégében hatástalannak bizonyultak [23-25].

\section{Következtetés}

$\mathrm{Az}$ EOM felismerése alapvető fontosságú a betegség megfelelő kezelése szempontjából. A diagnosztikát elősegíti a társbetegségek ismerete, a dobüregi váladékból vett minta citológiai vizsgálata pedig döntô fontosságú a korrekt diagnózis felállításához. A kezelés sikere elsősorban a korai felismerésen és a szteroidkészítmények rendszeres, IT alkalmazásában rejlik, melynek hatására a kezdeti stádiumban jó eredmény várható. A betegség nem gyógyítható, de a legtöbb esetben kezelhető. Konzervatív kezelésre nem reagáló esetekben a radikális fülészeti mütét kombinálása modern hallásjavító implantátummal jó eredményre vezethet.

Anyagi támogatás: A közlemény megírása, illetve a kapcsolódó kutatómunka anyagi támogatásban nem részesült.

Szerzői munkamegosztás: R. P.: A közlemény első szerzője, irodalmi kutatómunka, ábraszerkesztés. T. I.: A közlemény utolsó szerzője, a kézirat összeállítása, szakmai véleményezés. G. I., A. K; B. A.: Szakmai véleményezés. K. E.: Citológiai vizsgálat, kenet- és fényképkészítés. A cikk végleges változatát valamennyi szerző elolvasta és jóváhagyta.

\section{Érdekeltségek: A szerzőknek nincsenek érdekeltségeik.}

\section{Irodalom}

[1] Tomioka S, Kobayashi T, Takasaka T. Intractable otitis media in patients with bronchial asthma (eosinophilic otitis media). In: Sanna M. (ed.) Cholesteatoma and mastoid surgery. CIC Edizioni Internazionali, Rome, 1997; pp. 851-853.

[2] Ino Y, Tomioka-Matsutani S, Matsubara A, et al. Diagnostic criteria of eosinophilic otitis media, a newly recognized middle ear disease. Auris Nasus Larynx 2011; 38: 456-461.

[3] Iino $Y$, Nagamine H, Yabe T, et al. Eosinophils are activated in middle ear mucosa and middle ear effusion of patients with intractable otitis media associated with bronchial asthma. Clin Exp Allergy 2001; 31: 1135-1143.

[4] Nonaka M, Fukumoto A, Ozu C, et al. IL-5 and eotaxin levels in middle ear effusion and blood from asthmatics with otitis media with effusion. Acta Otolaryngol. 2003; 123: 383-387.

[5] Ino Y, Kakizaki K, Katano H, et al. Eosinophil chemoattractants in the middle ear of patients with eosinophilic otitis media. Clin Exp Allergy 2005; 35: 1370-1376.

[6] Kanazawa H, Yoshida N, Shinnabe A, et al. Antigen-specific IgE in middle ear effusion of patients with eosinophilic otitis media. Ann Allergy Asthma Immunol. 2014; 113: 88-92.

[7] Esu Y, Iino Y, Masuda M, et al. Proposal of a treatment strategy for eosinophilic otitis media based on middle ear condition. Otol Neurotol. 2018; 39: e671-e678.
[8] Iino Y, Usubuchi H, Kodama K, et al. Eosinophilic inflammation in the middle ear induces deterioration of bone-conduction hearing level in patients with eosinophilic otitis media. Otol Neurotol. 2010 ; 31: 100-104.

[9] Iino Y, Nagamine H, Kakizaki K, et al. Effectiveness of instillation of triamcinolone acetonide into the middle ear for eosinophilic otitis media associated with bronchial asthma. Ann Allergy Asthma Immunol. 2006; 97: 761-766.

[10] Kanazawa H, Yoshida N, Ino Y. New insights into eosinophilic otitis media. Curr Allergy Asthma Rep. 2015; 15: 76.

[11] Han YE, Kang YS, Cho Y, et al. Eosinophilic otitis media treated with anti-IgE monoclonal antibodies and a bone conduction implant. J Int Adv Otol. 2018; 14: 144-147.

[12] Fukuda A, Morita S, Nakamaru Y, et al. Differentiation between eosinophilic otitis media and otitis media associated with eosinophilic granulomatosis with polyangiitis. Otol Neurotol. 2019; 40: e796-e802.

[13] Suzuki H, Matsutani S, Kawase T, et al. Epidemiologic surveillance of "eosinophilic otitis media" in Japan. Otol Jpn 2004; 14: 112-117. [Japanese]

[14] Okano M, Fujiwara T, Haruna T, et al. Role of fungal antigens in eosinophilia-associated cellular responses in nasal polyps: a comparison with enterotoxin. Clin Exp Allergy 2011; 41: 171-178.

[15] Matsubara A, Takahata J, Miura T, et al. Treatment for eosinophilic otitis media. J Clin Cell Immunol. 2018; 9: 538.

[16] Parente L. Deflazacort: therapeutic index, relative potency and equivalent doses versus other corticosteroids. BMC Pharmacol Toxicol. 2017; 18: 1

[17] El Sabbagh NG, Sewitch MJ, Bezdjian A, et al. Intratympanic dexamethasone in sudden sensorineural hearing loss: a systematic review and meta-analysis. Laryngoscope 2017; 127: 18971908.

[18] Engel F, Blatz R, Schliebs R, et al. Bacterial cytolysin perturbs round window membrane permeability barrier in vivo: possible cause of sensorineural hearing loss in acute otitis media. Infect Immun. 1998; 66: 343-346.

[19] Takumida M, Anniko M. Localization of endotoxin in the inner ear following inoculation into the middle ear. Acta Otolaryngol. 2004; 124: 772-777.

[20] Bosman AJ, Kruyt IJ, Mylanus EA, et al. On the evaluation of a superpower sound processor for bone-anchored hearing. Clin Otolaryngol. 2018; 43: 450-455.

[21] Sugimoto H, Hatano M, Noda M, et al. Cochlear implantation in deaf patients with eosinophilic otitis media using subtotal petrosectomy and mastoid obliteration. Eur Arch Otorhinolaryngol. 2017; 274: 1173-1177.

[22] Fisch U, Mattox DE. (eds.) Microsurgery of the skull base. Georg Thieme Verlag, Stuttgart, 1988.

[23] Iino $Y$, Hara $M$, Hasegawa $M$, et al. Clinical efficacy of anti- $\operatorname{IgE}$ therapy for eosinophilic otitis media. Otol Neurotol. 2012; 33: $1218-1224$.

[24] Iino $Y$, Hara M, Hasegawa $M$, et al. Effect of omalizumab on biomarkers in middle ear effusion in patients with eosinophilic otitis media. Acta Otolaryngol. 2014; 134: 366-372.

[25] Neff BA, Voss SG, Carlson ML, et al. Treatment of eosinophilic otitis media with pegylated interferon-alpha $2 \mathrm{a}$ and $2 \mathrm{~b}$. Laryngoscope 2017; 127: 1208-1216.

A cikk a Creative Commons Attribution 4.0 International License (https://creativecommons.org/licenses/by/4.0/) feltételei szerint publikált Open Access közlemény, melynek szellemében a cikk bármilyen médiumban szabadon felhasználható, megosztható és újraközölhetö, feltéve, hogy az eredeti szerző és a közlés helye, illetve a CC License linkje és az esetlegesen végrehajtott módosítások feltüntetésre kerülnek. (SID_1) 